\title{
COMBINED SELECTION IN BEANS FOR CYCLE, PLANT ARCHITECTURE AND GRAIN YIELD
}

\author{
SELEÇÃO COMBINADA EM FEIJÃO PARA CICLO, ARQUITETURA DE PLANTA E \\ PRODUTIVIDADE DE GRÃOS
}

\section{Nerinéia Dalfollo RIBEIRO ${ }^{1}$; Greice Rosana KLÄSENER ${ }^{2}$; Henrique Caletti MEZZOMO $^{3}$; Micheli Thaise Della Flora POSSOBOM${ }^{4}$; Skarlet De Marco STECKLING ${ }^{3}$; Cleiton Renato CASAGRANDE ${ }^{2}$}

1. Professor Titular, Doutor, Departamento de Fitotecnia, Universidade Federal de Santa Maria - UFSM, Santa Maria, RS, Brasil. nerineia@ hotmail.com; 2. Graduando em Agronomia - UFSM, Santa Maria, RS, Brasil. 3. Mestrando em Agronomia - UFSM, Santa Maria, RS, Brasil. 4. Doutorando em Fitotecnia - Universidade Federal de Viçosa, Viçosa, MG, Brasil.

\begin{abstract}
The selection of common bean cultivars for high agronomic performance can be difficulty by genotype $\mathrm{x}$ environment interaction. The objectives of this work were to evaluate if common bean cultivars differ for cycle, plant architecture and grain yield in different growing seasons, and to select early, upright and highly grain yield common bean cultivars, by the use of selection index. For this, five experiments were conducted in the randomized blocks design, with three replicates. A total of 26 common bean cultivars were evaluated and the multiplicative index was used to select superior cultivars. A significant cultivar x season interaction for flowering, cycle, insertion of the first pod, insertion of the last pod, number of pods per plant and grain yield was observed. The common bean cultivars have early or semiearly cycle in rainy season and upright plant architecture. The cultivars Macanudo, BRS Campeiro, IAPAR 81, and IPR Juriti presented high grain yield in most growing seasons. The four superior common bean cultivars selected by the multiplicative index were BRS Campeiro, Macanudo, IPR Juriti, and Guapo Brilhante. The cultivars BRS Campeiro, Macanudo, and IPR Juriti presents earliness, upright plant architecture, and high grain yield and will be selected for the breeding program.
\end{abstract}

KEYWORDS: Phaseolus vulgaris. Genotype x environment interaction. Genealogy. Selection index.

\section{INTRODUCTION}

The development process of a common bean cultivar (Phaseolus vulgaris L.) by classic breeding demands years of work and a lot of effort in the selection of cultivars with high agronomic performance. However, the breeder's job does not end when a new common bean cultivar is registered. They need to continue to assess the agronomic performance of these new cultivars in the region of adaptation. In addition, these cultivars can be used in controlled crossings for the introgression of favorable alleles in new cultivars.

The newly registered common bean cultivars present a genetic progress when comparing the older cultivars. The annual genetic gain observed for grain yield was from 0.72 to $1.10 \%$ in common bean grown in Brazil (RIBEIRO et al., 2008; FARIA et al., 2013, 2014). This increase in grain yield has been followed by phenological, plant architecture, and yield potential modifications. The new common bean cultivars development by different breeding programs have earlier flowering and cycle (RIBEIRO et al., 2008), present more resistance to lodging and upright plant architecture (FARIA et al., 2013, 2014), and greater number of pods per plant (RIBEIRO et al., 2008). It was also possible to verify that the common bean cultivars registered after 2005 presented higher grain yield, adaptation and production stability when comparing the older cultivars (BARILI et al., 2015a,b).

The traits that confer high agronomic performance in common bean cultivars are affected by genotype $\mathrm{x}$ environment interaction. A significant genotype $\mathrm{x}$ environment interaction was described previously for flowering and life cycle (RIBEIRO et al., 2004; PEREIRA et al., 2012; MOURA et al., 2013; ZILIO et al., 2013; RIBEIRO et al., 2014a; MAMBRIN et al., 2015), insertion of the first and last pod (MOURA et al., 2013; RIBEIRO et al., 2014a; MAMBRIN et al., 2015; MAZIERO et al., 2015), number of pods per plant and grain yield (PEREIRA et al., 2009, 2012, 2014; ZILIO et al., 2011, 2013; MOURA et al., 2013; TORGA et al., 2013; RIBEIRO et al., 2014a,b; BARILI et al., 2015a,b; MAMBRIN et al., 2015) in common bean cultivars. The dissimilarity in the performance of common bean lines can be explained by the different minimum and maximum air temperature, rainfall distribution, and air relative humidity recorded in each growing season (RIBEIRO et al., 2014a,b; BARILI et al., 2015a,b; MAMBRIN et al., 2015). 
If the agronomic performance of the common bean cultivars is not constant in the growing environment, this would difficult the selection of superior cultivars. In addition, it is necessary to see if the genealogy is related to the agronomic performance of common bean cultivars in different growing environments. No information was found in previous literature that consider the effects of genotype $\mathrm{x}$ environment interaction, genealogy analysis, and selection indices for the selection of common bean cultivars with high agronomic performance.

Therefore, the objectives of this study were to evaluate if common bean cultivars differ for cycle, plant architecture and grain yield in different growing seasons, and to select early, upright and highly grain yield common bean cultivars by the use of selection index.

\section{MATERIAL AND METHODS}

Five experiments were carried out on a field area of the Department of Plant Sciences of Federal University of Santa Maria, Santa Maria, located at the geographic coordinates of $29^{\circ} 42^{\prime}$ south latitude and 53 $43^{\prime}$ ' longitude west of Greenwich, at an altitude of $95 \mathrm{~m}$, in the Central Depression of State of Rio Grande do Sul (RS), Brazil. Sowing was done in October in the experiments of the rainy season 2010, 2011, 2012 and 2013 and in February for the 2011 dry season, which correspond to growing traditional seasons of common bean in RS (Table 1).

Table 1. Meteorological data collected in the 8th Meteorology District, in Santa Maria Meteorological Station, set at the Federal University of Santa Maria $\left(29^{\circ} 42^{\prime} \mathrm{S}\right.$ lat, $53^{\circ} 43^{\prime} \mathrm{W}$ long, $95 \mathrm{~m}$ asl), in the State of Rio Grande do Sul Brazil.

\begin{tabular}{|c|c|c|c|c|c|}
\hline Growing season & Month & Rainfall & $\begin{array}{l}\text { Maximum } \\
\text { temperature }\end{array}$ & $\begin{array}{l}\text { Minimum } \\
\text { temperature }\end{array}$ & $\begin{array}{c}\text { Relative } \\
\text { humidity }\end{array}$ \\
\hline & & $\mathrm{mm}$ & ${ }^{\circ} \mathrm{C}$ & ${ }^{\circ} \mathrm{C}$ & $\%$ \\
\hline \multirow{4}{*}{2010 rainy season } & Oct & 49.30 & 24.42 & 12.65 & 71.33 \\
\hline & Nov & 71.30 & 27.79 & 14.88 & 66.48 \\
\hline & Dec & 157.90 & 30.39 & 18.32 & 67.12 \\
\hline & Jan & 127.10 & 32.45 & 21.62 & 76.85 \\
\hline \multirow{5}{*}{2011 dry season } & $\mathrm{Feb}$ & 165.80 & 30.02 & 20.77 & 78.60 \\
\hline & Mar & 54.90 & 28.85 & 17.97 & 75.64 \\
\hline & Apr & 164.90 & 26.58 & 14.71 & 79.93 \\
\hline & May & 54.90 & 21.51 & 12.00 & 83.98 \\
\hline & Jun & 99.00 & 19.21 & 9.09 & 80.99 \\
\hline \multirow{4}{*}{2011 rainy season } & Oct & 184.80 & 25.17 & 14.37 & 75.91 \\
\hline & Nov & 41.60 & 28.98 & 16.43 & 62.98 \\
\hline & Dec & 13.40 & 30.29 & 17.37 & 60.82 \\
\hline & Jan & 68.80 & 32.99 & 19.40 & 63.05 \\
\hline \multirow{4}{*}{2012 rainy season } & Oct & 255.20 & 25.70 & 16.74 & 79.74 \\
\hline & Nov & 72.80 & 30.39 & 17.48 & 70.49 \\
\hline & Dec & 293.00 & 31.14 & 19.90 & 77.87 \\
\hline & Jan & 145.30 & 30.27 & 18.17 & 75.81 \\
\hline \multirow{4}{*}{2013 rainy season } & Oct & 108.70 & 26.19 & 14.22 & 73.99 \\
\hline & Nov & 294.50 & 28.73 & 17.52 & 72.71 \\
\hline & Dec & 92.80 & 32.12 & 19.70 & 70.11 \\
\hline & Jan & 132.30 & 32.62 & 21.23 & 78.36 \\
\hline
\end{tabular}

The climate of the region is classified as cfa - humid subtropical, according to the Köppen classification (KUINCHTNER; BURIOL, 2001). The soil of the experimental unit is classified as typicall alitic Argisol, Hapludalf, belonging to the
Santa Maria mapping unit, and was prepared in the conventional manner. The fertilizers were applied according to the interpretation of the soil chemical analysis, aiming to provide the appropriate nutrients amounts for the development of the crop. At the 
base, $250 \mathrm{~kg} \mathrm{ha}^{-1}$ of the 5-30-20 formula (nitrogen, phosphorus and potassium) was applied and $20 \mathrm{~kg}$ $\mathrm{ha}^{-1}$ of nitrogen as urea (45\% nitrogen) was added as coverage at the growth stage of the first trifoliolate leaf (V3).

The experimental design used was randomized blocks with three repetitions. The treatments evaluated consisted of 26 common bean cultivars: 17 cultivars from the "black" commercial group and 9 cultivars from the "colors" commercial group. All these cultivars were registered on the National Register of Cultivars, in the Ministry of Agriculture, Livestock, and Supply for cultivation in Rio Grande do Sul between 1971 and 2010 (Table 2 ), and represent the commercial groups most consumed in Brazil. The experimental unit was composed of two $4.0 \mathrm{~m}$-long rows, spaced in 0.50 $\mathrm{m}$, and a useful area of $4 \mathrm{~m}^{2}$.

Table 2. Genealogy, growth habit (GH), breeding program (program) and year of registered of 26 common bean cultivars evaluated in five experiments carried out from 2010 to 2014.

\begin{tabular}{|c|c|c|c|c|}
\hline Cultivar & Genealogy & $\mathrm{GH}^{1}$ & Program $^{2}$ & Year \\
\hline \multicolumn{5}{|c|}{... "Black" commercial group... } \\
\hline Rio Tibagi & S-89-N (introduction of Costa Rica) & II & FEPAGRO & 1976 \\
\hline Guateian 6662 & Introduction of Costa Rica & II & FEPAGRO & 1979 \\
\hline $\begin{array}{l}\text { Macanudo } \\
\text { (BR IPAGRO 1) }\end{array}$ & A 358 [A $176(\mathrm{G} 4326 \times$ BAC 40)] & III & EMBRAPA & 1989 \\
\hline $\begin{array}{l}\text { Minuano } \\
\text { (BR IPAGRO 3) }\end{array}$ & A 358 [A 176 (G 4326 x XAN 40)] & III & EMBRAPA & 1991 \\
\hline Diamante Negro & XAN 87 / A 367 & II & EMBRAPA & 1991 \\
\hline $\begin{array}{l}\text { Macotaço } \\
\text { (BR IPAGRO 35) }\end{array}$ & A 358 [A 176 (G $4326 \times$ XAN 40)] & III & EMBRAPA & 1994 \\
\hline $\begin{array}{l}\text { Guapo Brilhante } \\
\text { (BR FEPAGRO 44) }\end{array}$ & XAN 125 / [BAT 336 (A83 x ICA Pijao)] & II & EMBRAPA & 1995 \\
\hline IPR Uirapurú & BAC29/PR 1711/3/NEP2/2/Puebla173ICapijao & II & IAPAR & 2000 \\
\hline BRS Valente & (Emgopa 201-Ouro / Ônix) // AN 512586 & II & EMBRAPA & 2001 \\
\hline IPR Graúna & $\begin{array}{l}\text { EP 173/2/Rio Iguaçu/ Great Northern Nebraska } 1 \text { sel \#27/3/Rio Tibagi/ } \\
\text { Cornell 49242/4/ IAPAR BAC 25/ 5/ IAPARBAC } 26\end{array}$ & II & IAPAR & 2002 \\
\hline BRS Campeiro & Mutation induction program for the Corrente cultivar by gama radiation & II & EMBRAPA & 2003 \\
\hline BRS 7762 Supremo & W22-34/ VAN163 & II & EMBRAPA & 2004 \\
\hline FEPAGRO 26 & Selection in the BR FEPAGRO 44 cultivar (Guapo Brilhante) & II & FEPAGRO & 2006 \\
\hline BRS Expedito & CNF 5491 / FT Tarumã & II & EMBRAPA & 2006 \\
\hline IPR Tiziu & IAPAR LP91-117/ IAC Uma & II & IAPAR & 2007 \\
\hline BRS Esplendor & CB911863 / AN9123293 & II & EMBRAPA & 2007 \\
\hline IPR Tuiuiú & LP96-72 / Xamego & II & IAPAR & 2010 \\
\hline \multicolumn{5}{|c|}{..."Colors" commercial group... } \\
\hline Carioca & Selection in producer’s crops (Palmital, São Paulo) & III & $\mathrm{IAC}$ & 1971 \\
\hline Iraí & Selection in producer's crops (Rio Grande do Sul) & I & FEPAGRO & 1981 \\
\hline Pérola & Selection in the Apore cultivar & III & EMBRAPA & 1996 \\
\hline IAPAR 81 & $\begin{array}{l}\text { \{BAT } 93 \times[\text { (Carioca99 x Great Northen Nebraska 1\#Sel27) x Sel Aroana }] \\
\text { x (A } 176 \times \text { A 259) }\}\end{array}$ & II & IAPAR & 1997 \\
\hline IPR Juriti & $\begin{array}{l}\text { BAT93 /2/ Carioca Sel.99 / Great Northen Nebraska } 1 \text { sel\#27 /3/ sel. } \\
\text { Aroana /4/ A176 / A259 /5/ II } 133 \text { / XAN87 }\end{array}$ & II & IAPAR & 2002 \\
\hline BRSMG Pioneiro & Backcrossing Rudá (recorrente) / Ouro Negro & II & EMBRAPA & 2005 \\
\hline BRS Estilo & EMP 250 / 4 / A 769 /// A 429 / XAN S52 // V 8025 / PINTO VI 114 & II & EMBRAPA & 2006 \\
\hline IPR Siriri & IAPAR 31/ IAC Akitã & II & IAPAR & 2007 \\
\hline IPR Tangará & LP 95 -92/ Pérola & II & IAPAR & 2008 \\
\hline
\end{tabular}

${ }^{1} \mathrm{GH}$ : growth habit - I: determinate; II: indeterminate with short guides; III: indeterminate with long guides. ${ }^{2}$ Program: EMBRAPA: Brazilian Agricultural Research Corporation; FEPAGRO: Agricultural Research State Foundation; IAPAR - Paraná Agronomic Institute; IAC - Campinas Agronomic Institute. 
The insects were controlled with the application of the insecticide Engeo Pleno (14.1\% of thiamethoxam and $10.6 \%$ of lambda-cyhalothrin, Syngenta Brasil, São Paulo, SP, Brazil), at $125 \mathrm{~mL}$ $\mathrm{ha}^{-1}$. The weeds were mechanically eliminated whenever necessary, in order to avoid competition with the crop. Diseases were not controled.

Flowering was evaluated in the period between the emergence (V1) and the opening of the first flower (R6), and the cycle in the interval between emergence (V1) and maturation (R9), that is, when pods dried and acquired the typical coloring of each cultivar. These traits were evaluated in the field, considering $51 \%$ of the plants in R6 and R9, respectively. When plants reach maturation, 10 plants were randomly collected from the useful area and the distance between the cotyledon node and the insertion of the first and last pod was measured. The number of pods per plant was also counted. The grain yield was determined by the extrapolation of the grains weight obtained from the useful area by hectare, at $13 \%$ average moisture.

The data were subjected to individual and joint analyses of variance. The $F$ test $(p<0.05)$ was used to evaluate the main fixed effects (cultivar and season) and the cultivar $\mathrm{x}$ season interaction. Homogeneity of residual variance was tested using the Hartley's maximum F test (CRUZ; REGAZZI, 1997). The means for different cultivars and for growing seasons were compared using the ScottKnott test $(p=0.05)$. The multiplicative index (SUBANDI et al., 1973) was used to obtain estimates of genetic gain in selection. The four superior cultivars were selected $(15 \%$ of the cultivars evaluated) with the best results in the simultaneous selection were presented. Analyses were performed with the aid of Microsoft Office Excel, and Genes software (CRUZ, 2013).

\section{RESULTS AND DISCUSSION}

The variance of the experimental error was homogeneous for all traits ( $p>0.05)$, enabling the joint analysis of variance. In the joint analysis of variance, a significant effect was observed for cultivar, season and cultivar $\mathrm{x}$ season interaction for all traits (Table 3). Therefore, the common bean cultivars differed for flowering, cycle, insertion of the first pod, insertion of the last pod, number of pods per plant and grain yield; the growing seasons were different for the meteorological conditions; and the agronomic performance of the common bean cultivars was variable in growing seasons. A significant cultivar $\mathrm{x}$ environment interaction has been described for phenological traits - flowering and cycle (RIBEIRO et al., 2004; PEREIRA et al., 2012; MOURA et al., 2013; ZILIO et al., 2013; RIBEIRO et al., 2014a; MAMBRIN et al., 2015); plant architecture - insertion of the first and last pod (MOURA et al., 2013; RIBEIRO et al., 2014a; MAMBRIN et al., 2015; MAZIERO et al., 2015); and production traits - number of pods per plant and grain yield (PEREIRA et al., 2009, 2012, 2014; ZILIO et al., 2011, 2013; MOURA et al., 2013; TORGA et al., 2013; RIBEIRO et al., 2014a,b; BARILI et al., 2015a,b; MAMBRIN et al., 2015) in experiments evaluating the performance of common bean cultivars. For these traits, the performance of common bean cultivars varied in function of the growing environment.

Table 3. Joint analysis of variance containing the degrees of freedom (DF), mean squares, mean and variation coefficient (VC, \%) for the flowering (FLO), cycle, insertion of the first pod (IFP), insertion of the last pod (ILP), number of pods per plant (NPP) e grain yield (YIELD) of 26 common bean cultivars, assessed in five experiments carried out from 2010 to 2014.

\begin{tabular}{|c|c|c|c|c|c|c|c|}
\hline \multirow{2}{*}{ Sources of variation } & \multirow[t]{2}{*}{ DF } & \multicolumn{6}{|c|}{ Mean square } \\
\hline & & $\begin{array}{l}\text { FLO } \\
\text { days }\end{array}$ & $\begin{array}{r}\text { CYCLE } \\
\text { days }\end{array}$ & $\begin{array}{l}\text { IFP } \\
\mathrm{cm}\end{array}$ & $\begin{array}{r}\text { ILP } \\
\mathrm{cm} \\
\end{array}$ & NPP & $\begin{array}{l}\text { YIELD } \\
\mathrm{kg} \mathrm{ha}^{-1}\end{array}$ \\
\hline Block/Season & 10 & 5.71 & 93.41 & 29.19 & 87.88 & 17.73 & 295990.81 \\
\hline Cultivar (C) & 25 & $12.39 *$ & $33.72 *$ & $46.68^{*}$ & $268.38 *$ & $54.59^{*}$ & $413532.67 *$ \\
\hline Season (S) & 4 & $2754.39 *$ & $2975.45^{*}$ & 2857.13* & 6452.39* & 910.83* & $31008044.84 *$ \\
\hline $\mathrm{C} \times \mathrm{S}$ & 100 & $5.06^{*}$ & $14.01 *$ & $17.55^{*}$ & $73.41 *$ & $20.65^{*}$ & 256764.84* \\
\hline Residue & 250 & 2.44 & 5.74 & 7.48 & 31.29 & 9.64 & 42374.81 \\
\hline Mean & & 35.59 & 78.59 & 19.04 & 46.57 & 12.04 & $1,543.87$ \\
\hline $\mathrm{VC}(\%)$ & & 4.39 & 3.05 & 14.37 & 12.01 & 25.80 & 13.33 \\
\hline
\end{tabular}

\footnotetext{
${ }^{1}$ Significant by the $\mathrm{F}$ test $(\mathrm{p}=0.05) .{ }^{\mathrm{ns}}=$ non-significant.
} 
Flowering varied from 23.7 (Iraí, 2011 dry season) to 45.3 days (BRS Estilo, 2013 rainy season) (Table 4). Zilio et al. (2013) and Mambrin et al. (2015) also observed a similar range for the flowering of common bean genotypes evaluated in different growing seasons. In the present study, the cultivar effect affected flowering significantly (Table 3). However, the application of the ScottKnott test did not result in stratification among the treatments in the 2010 rainy, 2011 dry, and 2011
RIBEIRO, N. D. et al.

rainy seasons (Table 4). On the 2012 and 2013 rainy seasons, two groups of cultivars were formed. In the 2012 rainy season, Iraí was the earliest cultivar for the flowering ( 27 days), differing significantly from the other cultivars evaluated. In the 2013 rainy season, the cultivars BRS Campeiro, BRS Expedito, BRS 7762 Supremo, BRS Valente, FEPAGRO 26, Guapo Brilhante, IPR Graúna, IPR Tuiuiú, Macanudo, Macotaço, Minuano, Rio Tibagi, IAPAR 81, IPR Juriti, and IPR Siriri had earlier flowering.

Table 4. Mean* number of days for flowering and cycle of 26 common bean cultivars assessed in the seasons 2010 rainy (2010 rs), 2011 dry (2011 ds), 2011 rainy (2011 rs), 2012 rainy (2012 rs), and 2013 rainy (2013 rs).

\begin{tabular}{|c|c|c|c|c|c|c|c|c|c|c|}
\hline \multirow{2}{*}{ Cultivar } & \multicolumn{5}{|c|}{ Flowering (days) } & \multicolumn{5}{|c|}{ Cycle (days) } \\
\hline & $2010 \mathrm{rs}$ & $2011 \mathrm{ds}$ & $2011 \mathrm{rs}$ & 2012 rs & 2013 rs & 2010 rs & $2011 \mathrm{ds}$ & $2011 \mathrm{rs}$ & 2012 rs & $2013 \mathrm{rs}$ \\
\hline BRS Campeiro & 39.7 a A & 28.7 a C & 30.3 a C & 35.0 a B & $40.3 \mathrm{~b} \mathrm{~A}$ & $75.0 \mathrm{~b} \mathrm{~B}$ & $85.3 \mathrm{~b} \mathrm{~A}$ & 76.0 a B & 73.7 a B & 74.0 a B \\
\hline BRS Esplendor & $41.0 \mathrm{a} \mathrm{A}$ & 27.3 a D & 30.3 a C & 37.0 a B & 43.3 a A & 81.0 a B & 89.0 a A & 75.3 a C & 74.3 a C & 76.7 a $\mathrm{C}$ \\
\hline BRS Estilo & 41.3 a B & 32.0 a D & 30.3 a D & 37.7 a C & 45.3 a A & 81.3 a B & 91.7 a A & 71.0 b D & 76.3 a C & 77.7 a $C$ \\
\hline BRS Expedito & 40.3 a A & 28.0 a D & 30.7 a C & 36.7 a B & $42.3 \mathrm{~b} \mathrm{~A}$ & 81.3 a B & 90.0 a A & $74.7 \mathrm{~b} \mathrm{C}$ & 74.3 a C & 76.0 a $\mathrm{C}$ \\
\hline BRS 7762 Supremo & $41.0 \mathrm{a} \mathrm{A}$ & 28.0 a D & 30.7 a C & 35.3 a B & $41.3 \mathrm{~b} \mathrm{~A}$ & 80.7 a B & 90.3 a $\mathrm{A}$ & $74.3 \mathrm{~b} \mathrm{C}$ & 78.7 a B & 78.0 a B \\
\hline BRS Valente & $41.0 \mathrm{a} \mathrm{A}$ & 28.0 a D & 31.3 a C & 37.3 a B & $40.0 \mathrm{~b} \mathrm{~A}$ & 81.3 a B & 89.3 a A & 71.3 b D & 75.0 a C & 77.7 a $C$ \\
\hline Diamante Negro & 41.3 a A & 28.7 a C & 29.7 a C & 36.7 a $B$ & 42.7 a A & 82.0 a B & 89.0 a $\mathrm{A}$ & $73.0 \mathrm{~b} \mathrm{C}$ & 72.7 b C & 76.7 a $C$ \\
\hline FEPAGRO 26 & $41.0 \mathrm{a} \mathrm{A}$ & 28.7 a C & 30.3 a C & 35.7 a B & $41.7 \mathrm{~b} \mathrm{~A}$ & 79.7 a B & 90.0 a A & 75.3 a C & 73.7 a C & 76.7 a $C$ \\
\hline Guapo Brilhante & 40.3 a A & 28.0 a D & 30.7 a C & 34.7 a B & $42.3 \mathrm{~b} \mathrm{~A}$ & 80.3 a B & 85.7 b A & $73.0 \mathrm{~b} \mathrm{C}$ & $71.3 \mathrm{~b} \mathrm{C}$ & 75.3 a $C$ \\
\hline Guateian 6662 & 37.0 a B & 28.7 a D & 32.3 a C & 36.3 a B & $43.0 \mathrm{a} \mathrm{A}$ & 78.7 a B & 88.7 a A & $74.3 \mathrm{~b} \mathrm{C}$ & 69.7 b D & 78.3 a B \\
\hline IPR Graúna & $41.7 \mathrm{a} \mathrm{A}$ & 29.3 a C & 29.0 a C & 36.3 a B & $41.3 \mathrm{~b} \mathrm{~A}$ & 79.0 a B & 88.7 a A & $72.7 \mathrm{~b} \mathrm{C}$ & 74.0 a C & 74.0 a C \\
\hline IPR Tiziu & $41.0 \mathrm{a} A$ & 28.0 a D & 31.3 a C & 38.0 a B & $43.0 \mathrm{a} \mathrm{A}$ & 81.0 a B & $87.7 \mathrm{~b} \mathrm{~A}$ & 80.0 a B & 74.0 a C & 79.3 a B \\
\hline IPR Tuiuiú & $41.0 \mathrm{a} \mathrm{A}$ & 29.7 a C & 30.7 a C & 37.3 a B & $42.3 \mathrm{~b} \mathrm{~A}$ & 81.7 a B & $92.0 \mathrm{a} \mathrm{A}$ & 79.3 a B & 74.7 a C & 77.7 a $C$ \\
\hline IPR Uirapurú & 41.0 a B & 29.3 a D & 31.7 a D & 36.0 a C & $44.0 \mathrm{a} \mathrm{A}$ & 81.0 a B & 88.7 a A & 77.3 a B & $72.3 \mathrm{~b} \mathrm{C}$ & 78.0 a B \\
\hline Macanudo & 39.3 a A & 27.0 a D & 30.0 a C & 35.7 a B & $40.0 \mathrm{~b} \mathrm{~A}$ & $76.0 \mathrm{~b} \mathrm{~B}$ & $85.7 \mathrm{~b} \mathrm{~A}$ & $75.0 \mathrm{~b} \mathrm{~B}$ & 75.7 a B & 73.7 a B \\
\hline Macotaço & 39.7 a A & 28.7 a C & 30.7 a C & 37.3 a B & $41.7 \mathrm{~b} \mathrm{~A}$ & 78.0 b B & 89.7 a A & $73.3 \mathrm{~b} \mathrm{C}$ & 71.7 b C & 75.3 a $B$ \\
\hline Minuano & $41.0 \mathrm{a} \mathrm{A}$ & 27.7 a $D$ & 31.3 a C & 36.3 a B & $40.7 \mathrm{~b} \mathrm{~A}$ & 76.3 b B & 86.7 b A & $71.0 \mathrm{~b} \mathrm{C}$ & $71.7 \mathrm{~b} \mathrm{C}$ & 75.3 a B \\
\hline Rio Tibagi & 39.7 a A & 29.0 a D & 32.3 a C & 37.3 a $B$ & $41.0 \mathrm{~b} \mathrm{~A}$ & 80.7 a $\mathrm{B}$ & 89.3 a A & 77.7 a $B$ & $71.3 \mathrm{~b} \mathrm{C}$ & 78.0 a B \\
\hline BRSMG Pioneiro & 40.7 a B & 29.3 a D & 32.3 a C & 34.7 a C & 43.3 a A & 80.0 a B & 90.3 a A & 76.3 a C & 74.3 a C & 79.7 a B \\
\hline Carioca & 40.0 a B & 28.0 a E & 30.7 a D & 36.3 a C & 43.7 a A & 76.7 b B & $85.7 \mathrm{~b} \mathrm{~A}$ & $74.0 \mathrm{~b} \mathrm{C}$ & $71.0 \mathrm{~b} \mathrm{C}$ & 77.7 a B \\
\hline IAPAR 81 & $41.0 \mathrm{a} \mathrm{A}$ & 29.7 a C & 32.0 a C & 37.7 a B & $41.7 \mathrm{~b} \mathrm{~A}$ & 81.7 a $B$ & 91.7 a A & $74.3 \mathrm{~b} \mathrm{C}$ & $72.0 \mathrm{~b} \mathrm{C}$ & 75.7 a C \\
\hline IPR Juriti & $41.0 \mathrm{a} \mathrm{A}$ & 29.0 a C & 29.3 a C & $37.0 \mathrm{a} \mathrm{B}$ & $42.0 \mathrm{~b} \mathrm{~A}$ & 81.7 a $\mathrm{B}$ & 90.3 a $\mathrm{A}$ & $72.0 \mathrm{~b} \mathrm{C}$ & 72.7 b C & 75.7 a $C$ \\
\hline IPR Siriri & 39.3 a B & 28.7 a $D$ & 30.0 a D & 35.0 a C & $42.0 \mathrm{~b} \mathrm{~A}$ & 80.7 a B & 88.3 a A & $72.0 \mathrm{~b} \mathrm{C}$ & 74.7 a C & 77.3 a $B$ \\
\hline IPR Tangará & 38.7 a B & 30.7 a C & 31.7 a C & 37.7 a B & 43.7 a A & 81.7 a B & 94.3 a A & $73.7 \mathrm{~b} \mathrm{C}$ & $73.0 \mathrm{~b} \mathrm{C}$ & 77.0 a $\mathrm{C}$ \\
\hline Pérola & 41.7 a A & 29.7 a C & 28.3 a C & 36.3 a B & 43.3 a A & 81.3 a B & 93.3 a A & $71.3 \mathrm{~b} \mathrm{C}$ & 74.3 a C & 78.0 a B \\
\hline Iraí & 37.7 a $B$ & 23.7 a D & 28.7 a C & 27.0 b C & 44.0 a $\mathrm{A}$ & $74.0 \mathrm{~b} \mathrm{~A}$ & 75.7 с A & 74.3 b A & 70.7 b B & 78.0 a $\mathrm{A}$ \\
\hline Mean & 40.3 & 28.6 & 30.6 & 36.1 & 42.3 & 79.7 & 88.7 & 74.3 & 73.4 & 76.8 \\
\hline $\mathrm{VC}(\%)$ & 4.5 & 5.2 & 5.2 & 3.7 & 3.6 & 2.0 & 2.6 & 3.4 & 3.8 & 3.3 \\
\hline
\end{tabular}

* Means not followed by the same lower case letter in the column differ by the Scott-Knott test $(\mathrm{p}=0.05)$, and uppercase letters on each row by the Scott-Knott test $(\mathrm{p}=0.05)$.

The greatest means for the flowering was obtained in the 2013 rainy season (42.3 days), and an increase was seen in the number of days for flowering of most of the cultivars evaluated. In this 
growing season, the highest rainfall volume recorded in the vegetative period (Table 1) may have contributed for the delay in beginning of flowering in the cultivars. The higher rainfall amount may contribute to a higher duration of vegetative and reproductive periods in common beans, as reported previously by Zilio et al. (2013).

The cycle of the common bean cultivars varied greatly within and among the growing seasons, with a minimum value verified for Guateian 6662 cultivar in the 2012 rainy season (69.7 days), and a maximum value for IPR Tangará cultivar in the 2011 dry season (94.3 days) (Table 4 ). These values were similar to the ones previously observed in competition experiments of common bean genotypes carried out in different years, seasons and growing locations (RIBEIRO et al., 2004; PEREIRA et al., 2012; ZILIO et al., 2013).

Common bean cultivars were classified in two cycles in the 2011 dry season: early (Iraí cultivar, 75.7 days) and normal cycle (other cultivars, 85.3 to 94.3 days), according to the stratification proposed by Del Peloso et al. (2009). Iraí was the only cultivar that presented an early cycle in all environments evaluated. The cultivars BRS Campeiro, Macanudo, Macotaço, Minuano, and Carioca presented early cycle in the 2010, 2011, 2012, and 2013 rainy seasons, and a normal cycle in the 2011 dry season. For the other common bean cultivars, the cycle classification was altered in the growing season. Similarly, Ribeiro et al. (2004) observed that the cycle of common bean cultivars varied a lot in the growing seasons, so it was not possible to identify cultivars with cycle predictability.

Iraí was the only cultivar with determinate growth habit (type I) evaluated in this study. Type I common bean cultivars had a flowering period from five to six days (DAWO et al., 2007) and do not produce vegetative nodes after flowering (BURATTO et al., 2007). These traits contributed so that Iraí cultivar presented smaller variation in the cycle duration among the cultivars evaluated. The other common bean cultivars evaluated have indeterminate growth habit with short (type II) or long (type III) guides (Table 2). The common bean cultivars with indeterminate growth are characterized by the higher duration of flowering period, from 15 to 30 days (DAWO et al., 2007) and continue to produce vegetative nodes even after flowering (BURATTO et al., 2007). Therefore, these cultivars are exposed to the variations in the environmental conditions by greater number of days during the reproductive period. This contributed for the greater variation observed for the cycle duration in the cultivars with indeterminate growth habit.

Regarding the growing seasons, the highest means for the cycle ( 88.7 days) was observed in the 2011 dry season. The hypothesis is that the lowest minimum and maximum means temperatures values registered in the 2011 dry season, especially during the pod filling to plant maturation period (Table 1), justifies the longer cycle of the common bean cultivars. In this situation, the necessary thermal sum to reach the end of the cycle in the common bean cultivars took longer to be accumulated.

The identification of common bean cultivars of early or semi-early cycle enables less time of soil use for cultivation and early harvest, representing market advantages for the farmers that perform rotate crops and commercialize the grains in periods of lower product supply (BURATTO et al., 2007). In the present study, all common bean cultivars evaluated presented an early or semi-early cycle in the 2010, 2011, 2012, and 2013 rainy seasons. In the 2011 dry season, only the Iraí cultivar had an early cycle. These results indicate that the cycle of common bean cultivars may be different in growing seasons, and highlight the importance of its characterization in the evaluation process and indication of common bean cultivars for a particular cultivation region.

The application of the Scott-Knott test enabled the differentiation among the common bean cultivars for the insertion of the first pod only in the 2012 rainy season (Table 5). In this season, the cultivars BRS Esplendor, Guateian 6662, IPR Tiziu, IPR Uirapurú, and IPR Tangará showed higher insertion of the first pod values. It is important to identify the common bean cultivars with higher insertion of the first pod for the manual and mechanized harvest because it reduces the contact of the pods with the soil, which would imply better grain quality and smaller incidence of diseases in the pods and grains (COSTA et al., 2008). Therefore, common bean cultivars that present insertion of the first pod equal to or above $12 \mathrm{~cm}$ are associated to the plants with upright architecture (MELO, 2009). In the present study, all common bean cultivars evaluated attended this criterion, except Guapo Brilhante that presented insertion of the first pod of $11.8 \mathrm{~cm}$ in the 2011 dry season. Similarly, Ribeiro et al. (2014a), Mambrin et al. (2015), and Maziero et al. (2015) observed that the insertion of the first pod of common bean lines and cultivars in growing at Brazil was above $11.8 \mathrm{~cm}$. These results show the effort of breeding programs in the development of common bean cultivars of upright architecture. 
Table 5. Mean* insertion of the first pod and insertion of the last pod of 26 common bean cultivars assessed in the seasons 2010 rainy (2010 rs), 2011 dry (2011 ds), 2011 rainy (2011 rs), 2012 rainy (2012 rs), and 2013 rainy (2013 rs).

\begin{tabular}{|c|c|c|c|c|c|c|c|c|c|c|}
\hline \multirow{2}{*}{ Cultivar } & \multicolumn{5}{|c|}{ Insertion of the first pod $(\mathrm{cm})$} & \multicolumn{5}{|c|}{ Insertion of the last pod $(\mathrm{cm})$} \\
\hline & $2010 \mathrm{rs}$ & $2011 \mathrm{ds}$ & $2011 \mathrm{rs}$ & $2012 \mathrm{rs}$ & $2013 \mathrm{rs}$ & $2010 \mathrm{rs}$ & $2011 \mathrm{ds}$ & $2011 \mathrm{rs}$ & $2012 \mathrm{rs}$ & 2013 rs \\
\hline BRS Campeiro & 16.7 a B & 15.8 a B & 18.9 a B & 27.9 с A & 21.3 a B & $37.5 \mathrm{c} \mathrm{B}$ & $41.4 \mathrm{~b} \mathrm{~B}$ & $43.5 \mathrm{~b} \mathrm{~B}$ & 67.0 a $\mathrm{A}$ & 47.5 a B \\
\hline BRS Esplendor & 18.3 a B & $17.1 \mathrm{a} \mathrm{B}$ & 20.1 a B & 34.8 a $\mathrm{A}$ & 18.0 a B & 52.7 a B & 51.7 a B & 53.3 a B & 63.7 a A & 30.7 b C \\
\hline BRS Estilo & 20.8 a B & $14.1 \mathrm{a} \mathrm{B}$ & 17.2 a B & $32.0 \mathrm{~b} \mathrm{~A}$ & $17.1 \mathrm{a} \mathrm{B}$ & $48.7 \mathrm{~b} \mathrm{~B}$ & $41.1 \mathrm{~b} \mathrm{C}$ & $45.9 \mathrm{~b} \mathrm{~B}$ & 62.3 a A & $34.1 \mathrm{~b} \mathrm{C}$ \\
\hline BRS Expedito & 18.7 a B & $16.1 \mathrm{a} \mathrm{B}$ & 16.4 a B & $32.0 \mathrm{~b} \mathrm{~A}$ & $17.1 \mathrm{a} \mathrm{B}$ & $45.1 \mathrm{~b} \mathrm{~B}$ & 46.7 a B & $48.3 \mathrm{~b} \mathrm{~B}$ & 60.4 a A & $31.5 \mathrm{~b} \mathrm{C}$ \\
\hline BRS 7762 Supremo & 14.6 a B & 13.3 a B & 16.3 a B & $30.3 \mathrm{~b} \mathrm{~A}$ & 18.1 a B & $42.0 \mathrm{c} \mathrm{B}$ & $39.0 \mathrm{~b} \mathrm{~B}$ & $43.8 \mathrm{~b} \mathrm{~B}$ & 56.8 a $\mathrm{A}$ & 41.9 a B \\
\hline BRS Valente & $15.1 \mathrm{a} \mathrm{B}$ & 12.8 a B & 17.5 a B & $30.5 \mathrm{~b} \mathrm{~A}$ & 14.5 a B & $46.6 \mathrm{~b} \mathrm{~B}$ & 44.6 a B & $47.5 \mathrm{~b} \mathrm{~B}$ & 58.9 a A & $36.4 \mathrm{~b} \mathrm{C}$ \\
\hline Diamante Negro & 14.9 a B & 15.2 a B & 18.6 a B & $26.5 \mathrm{c} \mathrm{A}$ & 17.7 a $B$ & $45.0 \mathrm{~b} \mathrm{~B}$ & 45.5 a B & $49.1 \mathrm{~b} \mathrm{~B}$ & 60.4 a A & $36.6 \mathrm{~b} \mathrm{C}$ \\
\hline FEPAGRO 26 & 15.9 a B & 16.4 a B & 14.9 a B & 27.9 с A & 19.3 a B & $42.2 \mathrm{c} \mathrm{B}$ & $42.5 \mathrm{~b} \mathrm{~B}$ & $43.0 \mathrm{~b} \mathrm{~B}$ & 54.9 a A & 38.2 a B \\
\hline Guapo Brilhante & 13.3 a C & 11.8 a C & 17.3 a B & 24.2 c A & 16.6 a B & 36.7 c B & $34.2 \mathrm{~b} \mathrm{~B}$ & 41.6 b B & $61.2 \mathrm{a} \mathrm{A}$ & $34.6 \mathrm{~b} \mathrm{~B}$ \\
\hline Guateian 6662 & 13.4 a B & 15.4 a B & 15.4 a B & 35.5 a $\mathrm{A}$ & 12.4 a B & 37.7 с C & $43.3 \mathrm{~b} \mathrm{~B}$ & 43.7 b B & 68.3 a $A$ & $31.8 \mathrm{~b} \mathrm{C}$ \\
\hline IPR Graúna & 13.9 a B & 14.0 a B & 16.7 a B & $28.4 \mathrm{c} \mathrm{A}$ & 16.3 a $B$ & 55.9 a A & $41.1 \mathrm{~b} \mathrm{~B}$ & 50.6 a A & $62.4 \mathrm{a} \mathrm{A}$ & 41.3 a B \\
\hline IPR Tiziu & 16.6 a B & 16.8 a B & 18.6 a B & 40.0 a $\mathrm{A}$ & 17.0 a B & $48.1 \mathrm{~b} \mathrm{C}$ & 43.6 b C & 53.7 a B & 67.9 a A & $33.2 \mathrm{~b} \mathrm{D}$ \\
\hline IPR Tuiuiú & 15.5 a B & 12.7 a B & 14.6 a B & $30.0 \mathrm{~b} \mathrm{~A}$ & 15.5 a B & $45.8 \mathrm{~b} \mathrm{~A}$ & $36.2 \mathrm{~b} \mathrm{~B}$ & $48.0 \mathrm{~b} \mathrm{~A}$ & 52.3 a A & $32.5 \mathrm{~b} \mathrm{~B}$ \\
\hline IPR Uirapurú & 16.4 a B & 15.3 a B & 19.3 a B & 35.5 a A & 14.9 a B & 49.6 b B & 45.9 a B & $47.5 \mathrm{~b} \mathrm{~B}$ & 60.1 a $\mathrm{A}$ & 29.0 b C \\
\hline Macanudo & 13.3 a A & 15.3 a A & 18.4 a A & $19.2 \mathrm{~d} \mathrm{~A}$ & $17.1 \mathrm{a} \mathrm{A}$ & $35.0 \mathrm{c} \mathrm{C}$ & $40.8 \mathrm{~b} \mathrm{C}$ & $48.3 \mathrm{~b} \mathrm{~B}$ & 58.7 a A & 46.6 a B \\
\hline Macotaço & 14.7 a B & 14.9 a B & 15.8 a B & $30.2 \mathrm{~b} \mathrm{~A}$ & 15.6 a B & 40.1 c B & 39.2 b B & 54.9 a A & 58.4 a A & 29.7 b C \\
\hline Minuano & 13.0 a B & 13.9 a B & 15.9 a B & $28.0 \mathrm{c} \mathrm{A}$ & $13.1 \mathrm{a} \mathrm{B}$ & $34.6 \mathrm{c} \mathrm{C}$ & $38.6 \mathrm{~b} \mathrm{C}$ & 49.6 b B & $62.1 \mathrm{a} \mathrm{A}$ & $34.7 \mathrm{~b} \mathrm{C}$ \\
\hline Rio Tibagi & 16.5 a B & 14.9 a B & 18.0 a B & $29.4 \mathrm{~b} \mathrm{~A}$ & 14.6 a B & $47.4 \mathrm{~b} \mathrm{~B}$ & 49.6 a B & $48.0 \mathrm{~b} \mathrm{~B}$ & 65.6 a A & $36.1 \mathrm{~b} \mathrm{C}$ \\
\hline BRSMG Pioneiro & 13.5 a B & 15.5 a B & 16.1 a B & $27.2 \mathrm{c} \mathrm{A}$ & 14.4 a B & $46.3 \mathrm{~b} \mathrm{~A}$ & 41.3 b B & 51.0 a A & 54.0 a A & $30.2 \mathrm{~b} \mathrm{C}$ \\
\hline Carioca & $14.1 \mathrm{a} \mathrm{B}$ & 18.0 a B & 20.1 a B & $31.8 \mathrm{~b} \mathrm{~A}$ & 15.9 a B & 34.7 c C & 47.0 a B & 53.8 a B & $61.4 \mathrm{a} \mathrm{A}$ & $28.4 \mathrm{~b} \mathrm{C}$ \\
\hline IAPAR 81 & 13.4 a B & 17.4 a B & 20.5 a B & 27.7 c A & 16.6 a B & 45.6 b B & 40.9 b B & 55.3 a A & 61.8 a A & 45.4 a B \\
\hline IPR Juriti & 15.7 a $B$ & 15.2 a B & 19.0 a B & $27.2 \mathrm{c} \mathrm{A}$ & 19.5 a B & $43.0 \mathrm{c} \mathrm{B}$ & 39.3 b B & 46.3 b B & $59.1 \mathrm{a} \mathrm{A}$ & 38.6 a B \\
\hline IPR Siriri & 17.2 a B & 16.9 a B & 18.7 a B & $33.0 \mathrm{~b} \mathrm{~A}$ & 14.8 a B & $47.5 \mathrm{~b} \mathrm{~B}$ & 48.6 a B & 52.8 a B & 66.1 a A & 38.7 a C \\
\hline IPR Tangará & 20.8 a B & 18.9 a $\mathrm{B}$ & 21.4 a B & 35.3 a A & 20.1 a B & 60.6 a $\mathrm{A}$ & 57.2 a A & 59.2 a A & 66.6 a $\mathrm{A}$ & 37.9 a B \\
\hline Pérola & 17.4 a B & 16.0 a B & 20.6 a B & $30.3 \mathrm{~b} \mathrm{~A}$ & 19.1 a B & 53.9 a A & 52.7 a A & 61.3 a A & 60.6 a A & $35.3 \mathrm{~b} \mathrm{~B}$ \\
\hline Iraí & 14.6 a A & 13.9 a A & 16.1 a A & $17.7 \mathrm{~d} \mathrm{~A}$ & 17.0 a A & 25.7 c B & 29.7 b B & 29.8 c B & 45.3 a $\mathrm{A}$ & $36.7 \mathrm{~b} \mathrm{~A}$ \\
\hline Mean & 15.7 & 15.3 & 17.8 & 29.7 & 16.7 & 44.1 & 43.2 & 48.8 & 60.6 & 36.1 \\
\hline $\mathrm{VC}(\%)$ & 11.1 & 13.4 & 15.9 & 13.3 & 15.4 & 10.7 & 10.2 & 10.4 & 11.4 & 17.7 \\
\hline
\end{tabular}

*Means not followed by the same lower case letter in the column differ by the Scott-Knott test $(\mathrm{p}=0.05)$, and uppercase letters on each row by the Scott-Knott test $(\mathrm{p}=0.05)$.

The insertion of the last pod is also an important trait for the selection of common bean cultivars of upright architecture. In this study, there was no differentiation among the common bean cultivars for the insertion of the last pod in the 2012 rainy season (Table 5). However, the cultivars BRS Estilo, Guapo Brilhante, Guateian 6662, IPR Tuiuiú, Minuano, and Iraí presented smaller insertion of the last pod in the 2010, 2011, and 2013 rainy seasons, and in the 2011 dry season. Mambrin et al. (2015), also identified common bean lines with smaller insertion of the last pod in different growing seasons, and that was associated to plants that are more compact and resistant to lodging. Selection through the smaller insertion of the last pod is promising for the common bean breeding program, because these plants keep their development more uniform, although there are variations for the environmental conditions (Table 1).

Common bean cultivars presented a number of pods per plant, ranging from 3.7 (Carioca, 2013 rainy season) to 30.7 (IPR Graúna, 2010 rainy season) (Table 6). These values were above the ones observed in experiments of common bean cultivars competition carried out in different seasons, years, and growing locations (ZILIO et al., 2011; 
RIBEIRO et al., 2014b; MAMBRIN et al., 2015). Therefore, the common bean cultivars present genetic variability for the number of pods per plant, which enables the selection of superior cultivars for this trait. However, superior cultivars for the number of pods per plant were not identified for all the growing seasons, suggesting that this is a quantitative character, and it is very influenced by the environment.

Table 6. Mean* number of pods per plant and grain yield of 26 common bean cultivars assessed in the seasons 2010 rainy (2010 rs), 2011 dry (2011 ds), 2011 rainy (2011 rs), 2012 rainy (2012 rs), and 2013 rainy (2013 rs).

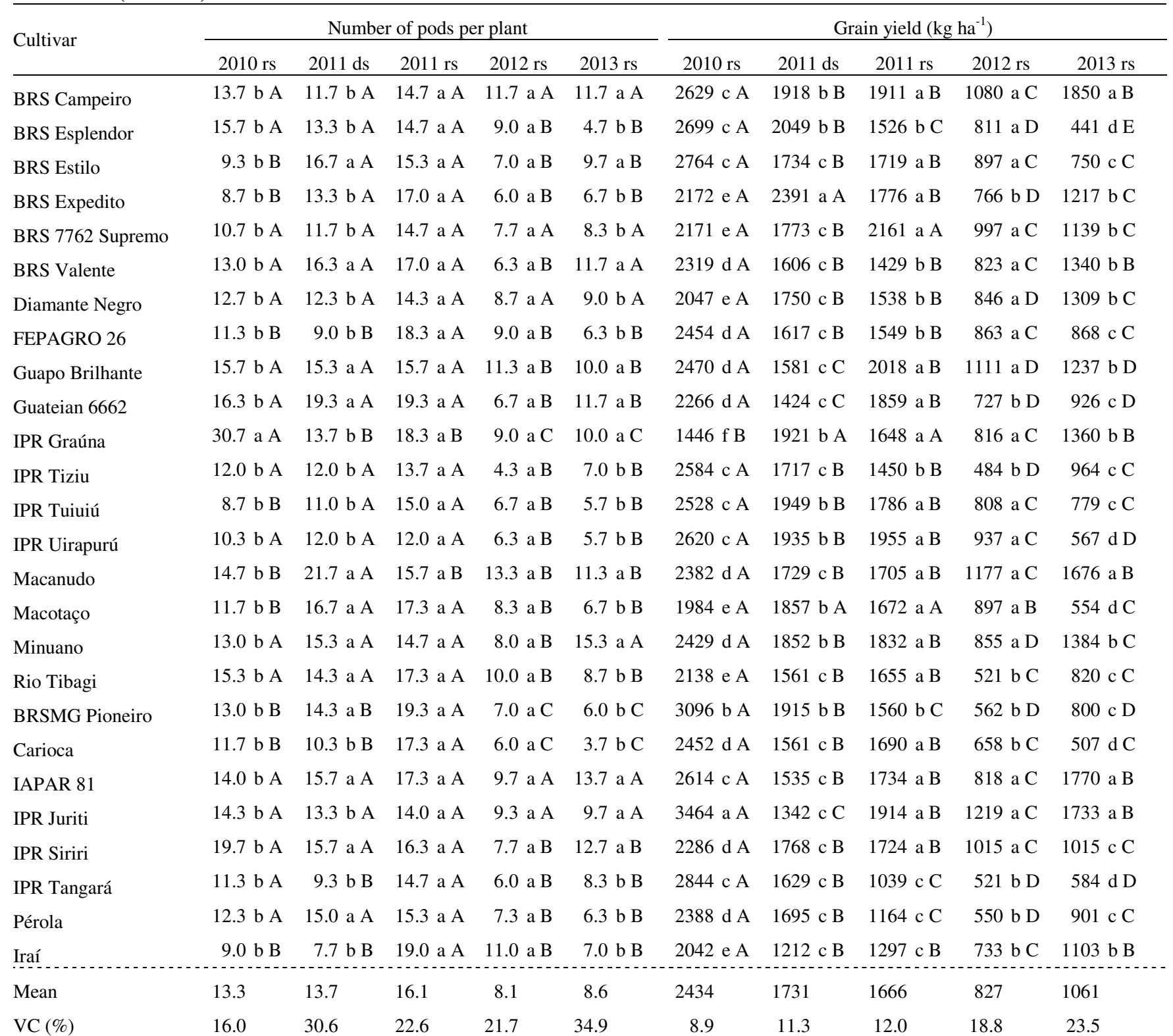

*Means not followed by the same lower case letter in the column differ by the Scott-Knott test $(\mathrm{p}=0.05)$, and uppercase letters on each row by the Scott-Knott test $(\mathrm{p}=0.05)$.

Grain yield varied a lot among the common bean cultivars, from $441 \mathrm{~kg} \mathrm{ha}^{-1}$ (BRS Esplendor, 2013 rainy season) to $3,464 \mathrm{~kg} \mathrm{ha}^{-1}$ (IPR Juriti, 2010 rainy season) (Table 6). In the present study, the identification of common bean cultivars with high grain yield for all the growing seasons was difficult, because the ranking of the cultivars was modified in each environment. In the 2010 rainy season, the cultivar that showed the highest grain yield was the IPR Juriti $\left(3,464 \mathrm{~kg} \mathrm{ha}^{-1}\right)$, while in the 2011 dry season was the BRS Expedito $\left(2,391 \mathrm{~kg} \mathrm{ha}^{-1}\right)$. The cultivars BRS Campeiro, BRS Estilo, BRS 7762 Supremo, Guapo Brilhante, IPR Graúna, IPR Tuiuiú, IPR Uirapurú, Macanudo, Macotaço, 
Minuano, IAPAR 81, IPR Juriti, and IPR Siriri fit the group with higher grain yield in the 2011 and 2012 rainy seasons. In turn, in the 2013 rainy season, the cultivars that stood out were BRS Campeiro, Macanudo, IAPAR 81, and IPR Juriti.

The cultivars Macanudo, BRS Campeiro, IAPAR 81, and IPR Juriti were grouped by the Scott-Knott test in the group of high grain yield in most of the growing seasons evaluated, which suggests adaptation to the cultivation conditions. The cultivars Macanudo and BRS Campeiro are from "black" commercial group and were registered by Brazilian Agricultural Research Corporation (EMBRAPA) in 1989 and in 2003, respectively (Table 2). The cultivars IAPAR 81 and IPR Juriti are Carioca-type beans (beige seed coat with brown streaks), and they were developed by the Paraná Agronomic Institute (IAPAR) and registered in 1997 and 2002, respectively. Therefore, they are cultivars that are being cultivated in Brazil, for a period of 15 to 29 years, and still present high grain yield potential of the grown for the rainy season, i. $\mathrm{e}$, when the sowing is done between September and November. Common bean cultivars registered after 2005 in Brazil showed low grain yield or stood out in specific season, indicating little adaptation to the cultivation conditions. This result is different from the one observed by Barilli et al. (2015a,b) in the Minas Gerais state, Brazil. In these experiments, the black and Carioca common bean cultivars registered after 2005 presented high grain yield, higher adaptation and production stability.

The black grains cultivars (Macanudo and BRS Campeiro) present a very different genealogy (Table 2). However, the Carioca grains cultivars (IAPAR 81 e IPR Juriti) have several parental in common in their genealogy, indicating greater genetic similarity. Thus, in the present study we did not see a direct relation between the genealogy of common bean cultivars and grain yield. Silva et al. (2011) did not see any relation between the origin of common bean cultivars and grain yield.

High heritability estimates were obtained for the all traits evaluated, so greater selection gains are expected for these traits (Table 7). The multiplicative index showed negative genetic gain values for flowering, cycle, insertion of the first pod, and insertion of the last pod, and positive genetic gain values for number of pods per plant and grain yield. These estimates are favorable to selection of superior common bean cultivars for earliness, upright plant architecture and grain yield, except for the insertion of the first pod. A negative sign of genetic gain for the insertion of the first pod is unfavorable for the selection. However, the four superior cultivars selected by the multiplicative index have insertion of the first pod superior to 16 $\mathrm{cm}$, which facilitates the manual and mechanized harvest of common bean plants according by Costa et al. (2008).

Table 7. Mean of the original population (Xo), mean of selected (Xs), heritability $\left(\mathrm{h}^{2}\right)$, genetic gain (GG) and percentage genetic gain (GG \%) with simultaneous selection by multiplicative index for the four superior cultivars assessed in five experiments carried out from 2010 to 2014.

\begin{tabular}{|c|c|c|c|c|c|c|c|c|c|}
\hline \multirow{2}{*}{ Trait* } & \multirow{2}{*}{ Xo } & \multirow{2}{*}{ Xs } & \multirow{2}{*}{$h^{2}$} & \multirow{2}{*}{ GG } & \multirow{2}{*}{ GG\% } & \multicolumn{4}{|c|}{ Selected cultivars } \\
\hline & & & & & & BRS Campeiro & Macanudo & IPR Juriti & G. Brilhante \\
\hline FLO & 35.59 & 35.02 & 80.32 & -0.46 & -1.29 & 34.80 & 34.40 & 35.67 & 35.20 \\
\hline CYCLE & 78.59 & 77.40 & 82.97 & -0.99 & -1.26 & 76.80 & 77.20 & 78.47 & 77.13 \\
\hline IFP & 19.03 & 18.18 & 83.96 & -0.72 & -3.77 & 20.11 & 16.66 & 19.32 & 16.63 \\
\hline ILP & 46.57 & 45.04 & 88.34 & -1.35 & -2.89 & 47.38 & 45.86 & 45.25 & 41.68 \\
\hline NPP & 11.98 & 13.39 & 82.64 & 1.17 & 9.74 & 12.61 & 15.24 & 12.15 & 13.56 \\
\hline YLD & 1543.87 & 1807.28 & 89.75 & 236.41 & 15.31 & 1877.52 & 1733.68 & 1934.50 & 1683.41 \\
\hline
\end{tabular}

*Trait: FLO: flowering, days; CYCLE, days; IFP: insertion of the first pod, cm; LPH: insertion of the last pod, cm; NPP: number of pods per plant; YLD: grain yield, $\mathrm{kg} \mathrm{ha}^{-1}$.

The multiplicative index showed selection gains sum of $15.84 \%$, which meets the objectives of this study by flowering $(-1.29 \%)$, cycle $(-1.26 \%)$, insertion of the last pod $(-2.89 \%)$, number of pods per plant $(+9.74 \%)$, and grain yield $(+15.31 \%)$. The four superior cultivars selected by the multiplicative index were BRS Campeiro, Macanudo, IPR Juriti, and Guapo Brilhante. These cultivars present earliness, upright plant architecture and high grain yield. Preliminary results showed that the multiplicative index was the most efficient strategy of simultaneous selection for the upright architecture and grain yield in common bean lines (JOST et al., 2012; MAZIERO et al., 2015). 
The cultivars BRS Campeiro, Macanudo, and IPR Juriti stood out due to their high grain yield in most of the growing seasons, have considering the effects of genotype $x$ environment interaction. These common bean cultivars presented early or semi-early cycle in grown carried out in the rainy season, and normal cycle in the dry season, and the insertion of the first pod is above $12 \mathrm{~cm}$. The three superior cultivars identified by the multiplicative index in present study were BRS Campeiro, Macanudo, and IPR Juriti. These cultivars present genealogy very different (Table 2), indicating lower genetic similarity. Therefore, the cultivars BRS Campeiro, Macanudo, and IPR Juriti cultivars presents earliness (flowering and cycle early), upright plant architecture (high insertion of the first pod and low insertion of the last pod) and high grain yield (higher values of number of pods per plant and grain yield), and so it will be selected for the breeding program.

\section{CONCLUSIONS}

The common bean cultivars differ for flowering, cycle, insertion of the first pod, insertion of the last pod, number of pods per plant, and grain yield in different growing seasons.

The cultivars BRS Campeiro, Macanudo, and IPR Juritipresents earliness, upright plant architecture and high grain yield, and so it will be selected for the breeding program.

\section{ACKNOWLEDGMENTS}

We thank the National Council of Technological and Scientific Development (CNPq) for the financial aid and scholarships granted. To the Research Support Foundation of the Minas Gerais State (FAPEMIG) for the grants awarded.

RESUMO: A seleção de cultivares de feijão com alto desempenho agronômico pode ser dificultada pela ocorrência de interação genótipo x ambiente. Os objetivos desse trabalho foram avaliar se cultivares de feijão diferem para ciclo, arquitetura de planta e produtividade de grãos em diferentes épocas de cultivo e selecionar cultivares de feijão precoces, eretas e altamente produtivas pelo uso de índice de seleção. Para tanto, cinco experimentos foram conduzidos em delineamento de blocos ao acaso, com três repetições. Um total de 26 cultivares de feijão foram avaliadas e o índice multiplicativo foi usado para selecionar cultivares superiores. Interação cultivar x época de cultivo significativa foi constatada para a floração, ciclo, inserção da primeira vagem, inserção da última vagem, número de vagens por planta e produtividade de grãos. As cultivares de feijão avaliadas possuem ciclo precoce ou semiprecoce no cultivo de safra e arquitetura de planta ereta. As cultivares Macanudo, BRS Campeiro, IAPAR 81 e IPR Juriti apresentaram alta produtividade de grãos na maioria das épocas avaliadas. As quatro melhores cultivares de feijão selecionadas pelo índice multiplicativo foram BRS Campeiro, Macanudo, IPR Juriti e Guapo Brilhante. As cultivares BRS Campeiro, Macanudo e IPR Juriti apresentam precocidade, arquitetura de planta ereta e alta produtividade de grãos, portanto serão selecionadas pelo programa de melhoramento.

PALAVRAS-CHAVE: Phaseolus vulgaris. Interação genótipo x ambiente. Genealogia. Índice de seleção.

\section{REFERENCES}

BARILI, L. D.; VALE, N. M. do; PRADO, A. L. do; CARNEIRO, J. E. de S.; SILVA, F. F.; NASCIMENTO, M. Genotype-environment interaction in common bean cultivars with carioca grain cultivated in Brazil in the last 40 years. Crop Breeding and Applied Biotechnology, Viçosa, v. 15, n. 4, p. 244-250,

2015a. https://doi.org/10.1590/0103-8478cr20141383

BARILI, L. D.; VALE, N. M. do; AMARAL, R. de C.; CARNEIRO, J. E. S.; SILVA, F. F.; CARNEIRO, P. C. $\mathrm{S}$. Adaptabilidade e estabilidade e a produtividade de grãos em cultivares de feijão preto recomendadas no Brasil nas últimas cinco décadas. Ciência Rural, Santa Maria, v. 45, n. 11, p. 1980-1986, 2015 b. http://dx.doi.org/10.1590/0103-8478cr20141383

BURATTO, J. S.; MODA-CIRINO, V.; FONSECA JÚNIOR, N. da S.; PRETE, C. E. C.; FARIA, R. T. Adaptabilidade e estabilidade produtiva em genótipos precoces de feijão no estado do Paraná. Semina: Ciências Agrárias, Londrina, v. 28, n. 3, p. 373-380, 2007. https://doi.org/10.5433/1679-0359.2007v28n3p373 
COSTA, J. G. C.; RAVA, C. A.; ZIMMERMANN, F. J. P.; MELO, L. C. Yield stability and adaptability of common bean lines developed by EMBRAPA. Pesquisa Agropecuária Tropical, Goiânia, v. 38, n. 2, p. 141$145,2008$.

CRUZ, C. D. GENES - a software package for analysis in experimental statistics and quantitative genetics. Acta Scientiarum. Agronomy, Maringá, v. 35, n. 3, p. 271-276, 2013. https://doi.org/10.4025/actasciagron.v35i3.21251

CRUZ, C. D.; REGAZZI A. J. Modelos biométricos aplicados ao melhoramento genético. 1. ed. Viçosa: Universidade Federal de Viçosa, 1997. 390 p.

DAWO, M. I.; SANDERS, F. E.; PILBEAM, D. J. Yield, yield components and plant architecture in the $F_{3}$ generation of common bean (Phaseolus vulgaris L.) derived from a cross between the determinate cultivar 'Prelude' and an indeterminate landrace. Euphytica, Wageningen, v. 156, n. 1, p. 77-88, 2007. https://doi.org/10.1007/s10681-007-9354-1

DEL PELOSO, M. J.; MELO, L. C.; PEREIRA, H. S.; FARIA, L. C. de; DIAZ, J. L. C.; WENDLAND, A. Cultivares de feijoeiro comum desenvolvidas pela Embrapa. In: FANCELI, A. L. (Ed.). Feijão: tópicos especiais de manejo. Piracicaba: ESALQ/USP, 2009. p. 23-40.

FARIA, L. C. de; MELO, P. G. S.; PEREIRA, H. S.; DEL PELOSO, M. J.; BRÁS, A. J. B. P.; MOREIRA, J. A. A.; CARVALHO, H. W. L. de; MELO, L. C. Genetic progress during 22 years of improvement of cariocatype common bean in Brazil. Field Crop Research, Amsterdam, v. 142, n. 1, p. 68-74, 2013. https://doi.org/10.1016/j.fcr.2012.11.016

FARIA, L. C. de; MELO, P. G. S.; PEREIRA, H. S.; WENDLAND, A.; BORGES, S. F.; PEREIRA FILHO, I. A.; DIAZ, A. L. C.; CALGARO, M.; MELO, L. C. Genetic progress during 22 years of black bean improvement. Euphytica, Wageningen, v. 199, n. 3, p. 261-272, 2014. https://doi.org/10.1007/s10681-014$1135-\mathrm{z}$

JOST, E.; RIBEIRO, N. D.; MAZIERO, S. M.; POSSOBOM, M. T. D. F.; ROSA, D. P.; DOMINGUES, L. da S. Comparison among direct, indirect and index selections on agronomic traits and nutritional quality traits in common bean. Journal of the Science of Food and Agriculture, London, v. 93, n. 5, p. 1097-1104, 2013. https://doi.org/10.1002/jsfa.5856

KUINCHTNER, A.; BURIOL, G. A. Clima do Estado do Rio Grande do Sul segundo a classificação climática de Köppen e Thornthwaite. Disciplinary Science, Santa Maria, v. 2, n. 1, p. 171-182, 2001.

MAMBRIN, R. B.; RIBEIRO, N. D.; STORCK, L.; DOMINGUES, L. da S.; BARKERT, K. A. Seleção de linhagens de feijão (Phaseolus vulgaris L.) baseada em caracteres morfológicos, fenológicos e de produção. Revista de Agricultura, Piracicaba, v. 90, n. 2, p. 141-155, 2015.

MAZIERO, S. M.; RIBEIRO, N. D.; STORCK, L. Simultaneous selection in beans for architecture, grain yield and minerals concentration. Euphytica, Wageningen, v. 205, n. 2, p. 369-380, 2015.

https://doi.org/10.1007/s10681-015-1392-5

MELO, L. C. Procedimentos para condução de experimentos de valor de cultivo e uso em feijoeiro comum. Santo Antônio de Goiás: Embrapa-CNPAF, 2009. 104 p. (Documento, 239).

MOURA, M. M.; CARNEIRO, P. C. S.; CARNEIRO, J. E. S.; CRUZ, C. D. Potencial de caracteres na avaliação da arquitetura de plantas de feijão. Pesquisa Agropecuária Brasileira, Brasília, v. 48, n. 4, p. 417 425, 2013. https://doi.org/10.1590/S0100-204X2013000400010 
PEREIRA, H. S.; MELO, L. C.; FARIA, L. C. de; DÍAZ, J. L. C.; DEL PELOSO, M. J.; COSTA, J. G. C. da; WENDLAND, A. Stability and adaptability of carioca common bean genotypes in states of the central South Region of Brazil. Crop Breeding and Applied Biotechnology, Viçosa, v. 9, n. 2, p.181-188, 2009. https://doi.org/10.1590/S0006-87052012005000024

PEREIRA, H. S.; ALMEIDA, V. M. de; MELO, L. C.; WENDLAND, A.; FARIA, L. C. de; DEL PELOSO, M. J.; MAGALDI, M. C. S. Influência do ambiente em cultivares de feijoeiro-comum em cerrado com baixa altitude. Bragantia, Campinas, v. 71, n. 2, p. 165-172, 2012. https://doi.org/10.1590/brag.2014.020

PEREIRA, H. S.; BUENO, L. G.; DEL PELOSO, M. J.; ABREU, A. F. B.; MOREIRA, J. A. A.; MARTINS, M.; WENDLAND, A.; FARIA L. C. de; SOUZA, T. L. P. O.; MELO, L. C. Agronomic perfomance and stability of andean common bean lines with white grains in Brazil. Bragantia, Campinas, v. 73, n. 2, p. 130137, 2014. http://dx.doi.org/10.1590/brag.2014.020

RIBEIRO, N. D.; JOST, E.; CARGNELUTTI FILHO, A. Efeitos da interação genótipo x ambiente no ciclo e na coloração do tegumento dos grãos do feijoeiro comum. Bragantia, Campinas, v. 63, n. 3, p. 373-380, 2004. https://doi.org/10.1590/S0006-87052004000300007

RIBEIRO, N. D.; CARGNELUTTI FILHO, A.; POERSCH, N. L.; JOST, E.; ROSA, S. S. da. Genetic progress in traits of yield, phenology and morphology of common bean. Crop Breeding and Applied Biotechnology, Viçosa, v. 8, n. 3, p. 232-238, 2008. https://doi.org/10.12702/1984-7033.v08n03a08

RIBEIRO, N. D.; DOMINGUES, L. da S.; GRUHN, E. M.; ZEMOLIN, A. E. M.; RODRIGUES J. de A. Desempenho agronômico e qualidade de cozimento de linhagens de feijão do grupo especiais. Revista Ciência Agronômica, Fortaleza, v. 45, n. 1, p. 92-100, 2014a. https://doi.org/10.1590/S1806-66902014000100012

RIBEIRO, N. D.; DOMINGUES, L. da S.; ZEMOLIN, A. E. M. Avaliação dos componentes da produtividade de grãos em feijão de grãos especiais. Científica, Jaboticabal, v. 42, n. 2, p. 178-186, 2014 b.

SILVA, C. A.; ABREU, A. de F. B.; RAMALHO, M. A. P.; CARNEIRO, J. E. de S. Implicações da origem das linhagens de feijoeiro na magnitude da interação com ambientes. Pesquisa Agropecuária Brasileira, Brasília, v. 46, n. 7, p. 720-728, 2011. https://doi.org/10.1590/S0100-204X2011000700007

SUBANDI, W.; COMPTON, A.; EMPIG, L. T. Comparison of the efficiencies of selection indices for three traits in two variety crosses of corn. Crop Science, Madison, v. 13, n. 2, p. 184-186, 1973.

TORGA, P. P.; MELO, P. G. S.; PEREIRA, H. S.; FARIA, L. C. de; DEL PELOSO, M. J.; MELO, L. C. Interaction of common bean cultivars of the black group with years, locations and sowing seasons. Euphytica, Wageningen, v. 189, n. 2, p. 239-248, 2013. https://doi.org/10.1007/s10681-012-0793-y

ZILIO, M.; COELHO, C. M. M.; SOUZA, C. A.; SANTOS, J. C. P.; MIQUELLUTI, D. J. Contribuição dos componentes de rendimento na produtividade de genótipos crioulos de feijão (Phaseolus vulgaris L.). Revista Ciência Agronômica, Fortaleza, v. 42, n. 2, p. 429-438, 2011. http://dx.doi.org/10.1590/S180666902011000200024

ZILIO, M.; SOUZA, C. A.; COELHO, C. M. M.; MIQUELLUTI, D. J.; MICHELS, A. F. Cycle, canopy architecture and yield of common bean genotypes (Phaseolus vulgaris) in Santa Catarina State. Acta Scientiarum. Agronomy, Maringá, v. 35, n. 1, p. 21-30, 2013. https://doi.org/10.1590/S180666902011000200024 